\title{
Hydrochemical characteristics and GIS-based assessment of groundwater quality in the coastal aquifers of Tuticorin corporation, Tamilnadu, India
}

\author{
S. Selvam • G. Manimaran • P. Sivasubramanian
}

Received: 23 May 2012/ Accepted: 19 November 2012/Published online: 8 December 2012

(C) The Author(s) 2012. This article is published with open access at Springerlink.com

\begin{abstract}
Tuticorin corporation stretches geographically from $8^{\circ} 43^{\prime}-8^{\circ} 51^{\prime} \mathrm{N}$ latitude and $78^{\circ} 5^{\prime}-78^{\circ} 10^{\prime} \mathrm{E}$ longitude, positioned in the East-West International sea routes on the South-East coast of India. The rapid urban developments in the past two decades of Tuticorin have caused depletion of groundwater quantity, and deterioration of quality through excessive consumption and influx of pollutants from natural and anthropogenic activities. The water samples collected in the field were analyzed for electrical conductivity, $\mathrm{pH}$, total dissolved solids, major cations like calcium, magnesium, sodium, potassium, and anions SUCH AS bicarbonate, carbonate, chloride, nitrate and sulfate, in the laboratory using the standard methods given by the American Public Health Association. In order to assess the groundwater quality, 36 groundwater samples had been collected in year 2011. The geographic information system-based spatial distribution map of different major elements has been prepared using ArcGIS 9.2. The Piper plot shows that most of the groundwater samples fall in the field of $\mathrm{Ca}^{2+}-\mathrm{Mg}^{2+}-\mathrm{Cl}^{-}-\mathrm{SO}_{4}{ }^{2-}$ and $\mathrm{Na}^{+}-\mathrm{K}^{+}-\mathrm{Cl}^{-}$ $-\mathrm{HCO}_{3}{ }^{-}$by projecting the position on the plots in the triangular field. The cation concentration indicate that 83,39 and $22 \%$ of the $\mathrm{K}^{+}, \mathrm{Na}^{+}, \mathrm{Ca}^{2+}$ concentrations exceed the WHO limit. As per Wilcox's diagram and US Salinity laboratory classification, most of the groundwater samples are not suitable for irrigation due to the presence of high salinity and medium sodium hazard. Irrigation waters classified based on sodium absorption ratio, have revealed that $52 \%$ groundwater are in general safe for irrigation, which needs treatment before use. permeability index also
\end{abstract}

S. Selvam $(\bowtie) \cdot$ G. Manimaran · P. Sivasubramanian Department of Geology, V.O.Chidambaram College, Thoothukudi 628008, Tamilnadu, India e-mail: geoselvam10@gmail.com indicates that the groundwater samples are suitable for irrigation purpose.

Keywords Groundwater quality - Geographic information system · Wilcox's diagram · Permeability index $\cdot$ Tuticorin corporation $\cdot$ WHO

\section{Introduction}

Water is the most important natural resource, which forms the core of ecological system. Recently there has been overall development in various fields such as agriculture, industry and urbanization in India. This has lead to increase in the demand of water supply which is met mostly from exploitation of groundwater resources. Hydrochemical study is a useful tool to identify the suitability of the groundwater. The physical parameters taken into consideration in the present study are color, odor, turbidity and temperature. The chemical parameters taken into consideration are hydrogen ion concentration $(\mathrm{pH})$, specific conductance (EC), total dissolved solids (TDS), total hardness $(\mathrm{TH})$ and all major cations and anions. Various workers in our country had carried out extensive studies on water quality have studied groundwater chemistry of shallow aquifers in the coastal zones of have concluded that groundwater present in the shallow aquifers are poor in quality and beyond potable limit as per the standard set by WHO (Amer 1995; Chidambaram et al. 2009; Dar et al. 2010). In many coastal towns or cities, groundwater seems to be the only source of fresh water to meet domestic, agricultural and industrial needs. But groundwater is under constant threat of saline water incursion, which seems to have become a worldwide concern (Rajmohan et al. 1997; Dar et al. 2011). The rapid growth in population in India 
enhanced the groundwater salinity through excessive consumption of groundwater for agricultural, domestic and industrial purposes due to the lack in surface water sources and high water demand. Moreover, high evaporation and low and erratic rainfall depleted the groundwater level and available groundwater quantity, especially in the coastal areas, and resulted in seawater intrusion (Adepelumi et al. 2009; Rajmohan et al. 2003; Todd 1959). Consequently, several agriculture farms near to the coast are abandoned due to groundwater salinity. Further, many inland farms have also been abandoned and groundwater in most of the farms is even not supporting date palms though date palms are very tolerant to salinity (Rajmohan et al. 2003; Selvam and Sivasubramanian 2012). Hence, it is apparent that recent studies firmly argue the effect of natural and anthropogenic contamination sources on groundwater composition, especially in coastal aquifer, and also imply the necessity of groundwater contamination studies in coastal aquifer. In the present study, a detailed investigation was carried out to evaluate the geochemical processes regulating groundwater quality in coastal aquifers of Tuticorin region since the groundwater has been impaired by natural as well as anthropogenic activities. Anthropogenic activities can alter the relative contributions of the natural causes of variations and also introduce the effects of pollution (Whittemore et al. 1989).

Geographic information system (GIS) has emerged as a powerful tool for storing, analyzing and displaying spatial data, and using these data for decision making in several areas including engineering and environmental fields (Goodchild 1993). The purpose of the study is to understand the groundwater quality in the coastal area and prepare the spatial distribution map of the various physico-chemical parameters using the GIS. In this study, GIS is utilized to locate groundwater quality zones suitable for different usages such as irrigation and domestic.

\section{Study area}

Tuticorin is located on the southeast coat of Tamilnadu, India. Historically, Tuticorin is famous for its maritime activity and pearl culture. It was the seaport of the Pandyan kingdom; it was later taken over by the Portuguese in 1548,
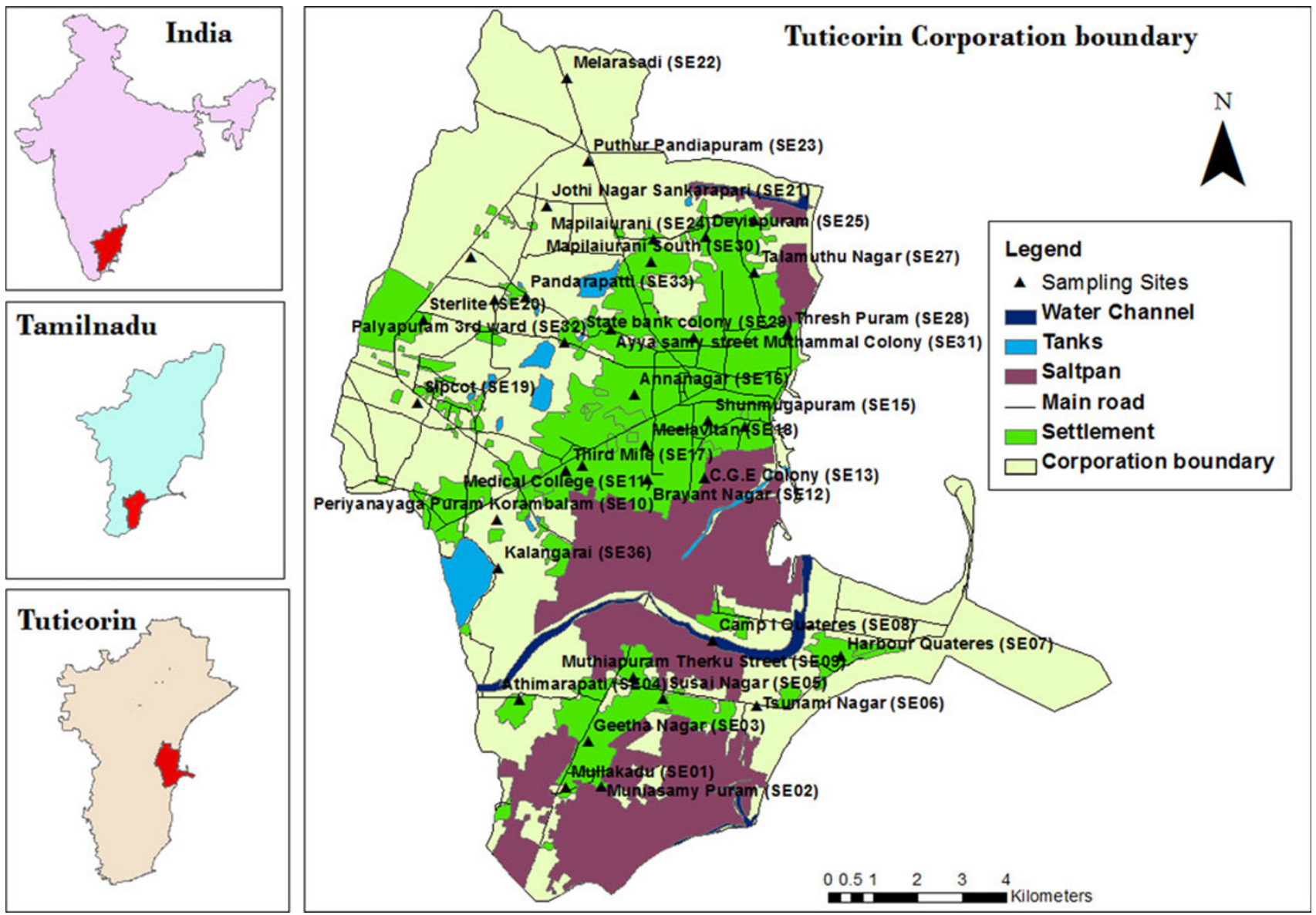

Fig. 1 Location map of study area 


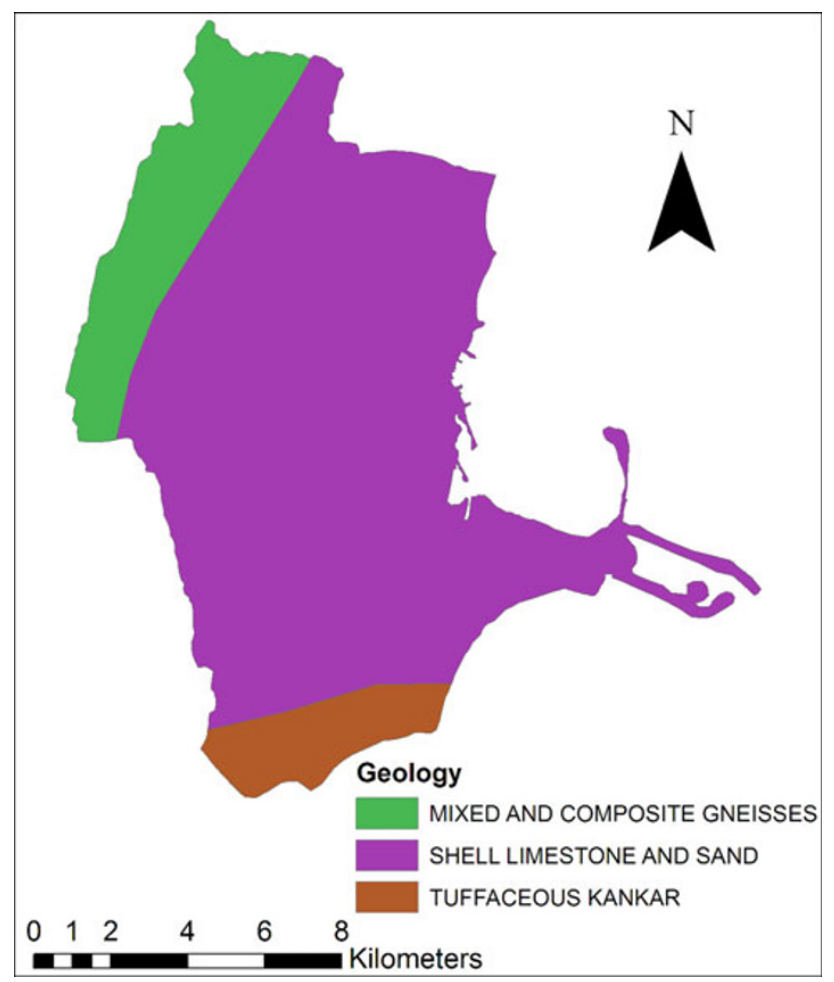

Fig. 2 Geology map of study area

captured by the Dutch in 1658, and ceded to the British in 1825. The lighthouse built in 1842 marked the beginning of the history of harbor development in the city. Tuticorin was established as a Municipality in 1866. It attained the status of Corporation on 5th August 2008 after 142 years. The city was industrially developed after the port construction and became district head quarters in the year 1986. After the formation of the district head quarters, the economic development was boosted and began to develop rapidly. Therefore, the urban expansion takes place in the different parts of the city during the study period. The study area covers geographical area of $154 \mathrm{sq} \mathrm{km}$ and lies between $8^{\circ} 43^{\prime}-8^{\circ} 51^{\prime} \mathrm{N}$ latitude and $78^{\circ} 5^{\prime}-78^{\circ} 10^{\prime} \mathrm{E}$ longitude (Fig. 1). Topographic elevation varies from few meters (near the coastline) to $27 \mathrm{~m}$ (amsl) in western part of the study area. The slope is gentle in the western and the central part, and nearly flat in the eastern part. Rainfall data from seven stations over the period of 1901-2008 were utilized and a perusal of the data shows that the normal annual rainfall over the district varies from about $570-740 \mathrm{~mm}$. It is minimum around Arasadi $(577.4 \mathrm{~mm})$ and Tuticorin $(582.8 \mathrm{~mm})$ in the central eastern part of the district. The district is covered by Black Cotton soil in the west, with isolated red soil patches in high ground. The sandy soil is present in the coastal tract. Alluvial soil is restricted to river flood plain and coastal part. Alkaline and saline soils are also noticed at places. Tuticorin is covered by long and extensive sandy beach. It trends in north-south direction. Well-developed sandy beach is identified below south harbor breakwater. This beach is dominated by an admixture of quartz, feldspars and mica minerals.

Geology and hydrology

About $90 \%$ of the study area is made up of sedimentary rocks of Tertiary to Recent age comprising Shell limestone and sand, tuffaceous kankar, sand (Aeolian deposits) etc., and the remaining area is covered by mixed and composite Genesis of Proterozoic age of crystalline rocks (Fig. 2). The Archean groups of formations are crystalline and metamorphic, and finely foliated with a general NW-SE trend described by Balasubramanaian et al. (1993) and Rangarajan et al. (2009).

The study area is covered with black soils in the western part (Sankarapari area), red soil (sandy loam to sandy soil) in the central part and alluvial sandy soils (Coastal area) in the eastern part. The maximum soil thickness is about $3 \mathrm{~m}$. The sandy soils originated from sandstones and these have low soil moisture retentively. The alluvium soils are windblown sands and shells constitute beach sand and coastal dunes, which have very low soil moisture retentivity. The important aquifer systems in the district are constituted by unconsolidated and semi consolidated formations and weathered and fractured crystalline rocks. The porous formations in the district include sandstones of Tertiary age. The Recent formations comprising mainly sands, clays and gravels are confined to major drainage courses in the district. The maximum thickness of alluvium is $45.0 \mathrm{~m} \mathrm{bgl}$, whereas the average thickness is about $25.0 \mathrm{~m}$. Groundwater occurs under water table and confined conditions in these formations and is being developed by means of dug wells and filter points. The productive zones are encountered in the depth range of $29.5-62.0 \mathrm{~m} \mathrm{bgl}$.

\section{Materials and methods}

A total of 36 groundwater samples had been collected from open wells and bore wells, well distributed within the study area during June 2011 and analyzed to understand the chemical variations of water quality parameters using standard methods (APHA 1995) (Table 1). The samples were collected in one liter high density polyethylene (HDPE) bottles pre-washed with dilute hydrochloric acid and rinsed three times with the water sample before filling and labeled accordingly. The samples were stored at a temperature $4{ }^{\circ} \mathrm{C}$ prior to analysis in the laboratory. Samples were analyzed in the laboratory for the physicochemical attributes such as $\mathrm{pH}$, electrical conductivity (EC), total hardness (TH), total dissolved solids (TDS) and major cations, such as calcium $(\mathrm{Ca})$, magnesium $(\mathrm{Mg})$, 
Table 1 Well inventory and characteristics in the study area

\begin{tabular}{|c|c|c|c|c|c|c|c|}
\hline Location name & Latitude & Longitude & Total depth (m) & Depth to water table (m) & $\mathrm{pH}$ & $\mathrm{EC}(\mu \mathrm{s} / \mathrm{cm})$ & TDS \\
\hline Mullakadu & 78.1158 & 8.7241 & 12 & 7 & 7.8 & 2,430 & 1,450 \\
\hline Muniasamy Puram & 78.123 & 8.7243 & 13.6 & 11.4 & 7.8 & 2,640 & 1,570 \\
\hline Geetha nagar & 78.1204 & 8.7335 & 13 & 8.7 & 7.4 & 3,900 & 2,400 \\
\hline Athimarapati & 78.1064 & 8.7418 & 10.3 & 7.1 & 7.8 & 1,080 & 710 \\
\hline Susai nagar & 78.1356 & 8.7421 & 19.3 & 15.4 & 7.4 & 4,180 & 2,700 \\
\hline Tsunami nagar & 78.1548 & 8.7407 & 13.6 & 9.5 & 7.7 & 1,520 & 980 \\
\hline Harbor quateres & 78.1721 & 8.7509 & 9.2 & 5.5 & 7.7 & 1,280 & 790 \\
\hline Camp I quateres & 78.1459 & 8.7541 & 19.6 & 13.1 & 7.6 & 10,000 & 6,000 \\
\hline Muthiapuram & 78.1297 & 8.7466 & 19 & 16 & 7.4 & 2,720 & 1,620 \\
\hline Periyanayaga Puram & 78.1016 & 8.7785 & 19.6 & 11.3 & 7.6 & 10,550 & 6,300 \\
\hline Medical college & 78.1193 & 8.7895 & 18 & 12 & 7.6 & 2,350 & 1,470 \\
\hline Brayant nagar & 78.1325 & 8.7869 & 16 & 13 & 7.7 & 1,840 & 1,840 \\
\hline C.G.E colony & 78.1441 & 8.7872 & 22 & 17.5 & 7.7 & 10,470 & 6,500 \\
\hline Fisher colony & 78.1525 & 8.7975 & 15.3 & 9 & 7.9 & 1,900 & 1,170 \\
\hline Shunmugapuram & 78.1449 & 8.7987 & 16 & 8 & 7.4 & 2,570 & 1,570 \\
\hline Annanagar & 78.1298 & 8.8041 & 9.3 & 5 & 7.5 & 2,490 & 1,560 \\
\hline Third mile & 78.1159 & 8.7885 & 16.3 & 10.2 & 7.8 & 910 & 580 \\
\hline Meelavitan & 78.1321 & 8.7937 & 19.8 & 15 & 7.1 & 8,720 & 5,300 \\
\hline Sipcot & 78.0855 & 8.8024 & 29.5 & 25 & 7.8 & 1,830 & 1,150 \\
\hline Sterlite & 78.0866 & 8.8192 & 70 & 30 & 8.8 & 4,810 & 3,100 \\
\hline Jothi nagar & 78.1118 & 8.8423 & 50 & 28 & 10.2 & 2,000 & 1,290 \\
\hline Melarasadi & 78.1161 & 8.8686 & 29 & 22 & 7.5 & 12,650 & 7,600 \\
\hline Puthur Pandiapuram & 78.1203 & 8.8516 & 32.3 & 19 & 8 & 1,440 & 910 \\
\hline Mapilaiurani & 78.1338 & 8.8357 & 16.9 & 9.5 & 8.1 & 350 & 2,300 \\
\hline Devispuram & 78.1445 & 8.8361 & 46 & 18.5 & 7.5 & 6,200 & 3,800 \\
\hline Siluvaipatti & 78.1545 & 8.8395 & 18 & 15 & 7.4 & 19,100 & 10,200 \\
\hline Talamuthu Nagar & 78.1544 & 8.8289 & 20.3 & 13 & 7.7 & 12,820 & 7,600 \\
\hline Thresh puram & 78.1613 & 8.8163 & 16.3 & 7.3 & 7.8 & 2,630 & 1,580 \\
\hline State bank colony & 78.1419 & 8.8155 & 16.3 & 4.4 & 7.5 & 2,780 & 1,700 \\
\hline Mapilaiurani south & 78.1333 & 8.8311 & 9.6 & 5.5 & 7.5 & 7,730 & 4,800 \\
\hline Ayya samy street & 78.1251 & 8.8172 & 16.3 & 8 & 8 & 3,160 & 1,940 \\
\hline Palyapuram & 78.1156 & 8.8146 & 19.6 & 8.1 & 7.9 & 7,500 & 4,500 \\
\hline Pandarapatti & 78.1074 & 8.8237 & 49 & 27 & 7.9 & 2,600 & 1,570 \\
\hline Vijay company & 78.0964 & 8.832 & 76 & 15 & 7.9 & 7,900 & 4,800 \\
\hline Sankarperi entrance & 78.1012 & 8.8233 & 19.3 & 15 & 7.5 & 8,070 & 4,700 \\
\hline Kalangarai & 78.1019 & 8.7688 & 25.4 & 11.2 & 7.9 & 840 & 530 \\
\hline
\end{tabular}

sodium $(\mathrm{Na})$, potassium $(\mathrm{K})$, and anions, such as bicarbonate $\left(\mathrm{HCO}_{3}\right)$, carbonate $\left(\mathrm{CO}_{3}\right)$, chloride $(\mathrm{Cl})$, nitrate $\left(\mathrm{NO}_{3}\right)$ sulfate $\left(\mathrm{SO}_{4}\right)$, and phosphate $\left(\mathrm{PO}_{4}\right)$ in the laboratory using the standard methods given by the American Public Health Association (APHA 1995). These parameters are tabulated in Table 2. $\mathrm{pH}, \mathrm{EC}$ and TDS were measured using portable water quality analyzers. Major cations $(\mathrm{Ca}$, $\mathrm{Mg}, \mathrm{Na}$, and $\mathrm{K}$ ) were determined using ICP-mass spectrometer while the anions were determined as follows: bicarbonate $\left(\mathrm{HCO}_{3}\right)$, and total hardness $(\mathrm{TH})$ were analyzed by volumetric method and sulfate $\left(\mathrm{SO}_{4}\right)$ was estimated by the spectrophotometric technique and nitrate $\left(\mathrm{NO}_{3}\right)$ was determined by ion chromatography. Chloride (Cl) by volumetric titration using $\mathrm{AgNO}_{3}$ and $\mathrm{K}_{2} \mathrm{Cr}, \mathrm{HCO}_{3}$ and carbonate $\left(\mathrm{CO}_{3}\right)$ was determined by Portamess using $\mathrm{HCl}$, phenolphthalein, methyl orange by titration method. Fluoride was estimated using an ion-selective electrode (ISE) with a pH/ISE meter (Orion 4-Star meter). All concentrations are expressed in milligrams per liter $(\mathrm{mg} / \mathrm{l})$, except $\mathrm{pH}$ and EC. The results were evaluated in accordance with the drinking water quality standards given by the World Health Organization (WHO 2004). 
Table 2 Descriptive statistics of the groundwater samples in Tuticorin corporation area

\begin{tabular}{llllll}
\hline $\begin{array}{l}\text { Water quality } \\
\text { parameters }\end{array}$ & Units & $\begin{array}{l}\text { Minimum } \\
\text { concentration }\end{array}$ & $\begin{array}{l}\text { Maximum } \\
\text { concentration }\end{array}$ & Average & SD \\
\hline $\mathrm{pH}$ & - & 7.1 & 10.2 & 7.6 & 7.8 \\
$\mathrm{EC}$ & $\mu \mathrm{S} / \mathrm{cm}$ & 350 & 19,100 & $4,887.778$ & $4,332.83$ \\
$\mathrm{TDS}$ & $\mathrm{mg} / \mathrm{l}$ & 530 & 10,200 & $3,016.111$ & 2426.35 \\
$\mathrm{Na}$ & $\mathrm{mg} / \mathrm{l}$ & 27 & 1,400 & 408.777 & 430.13 \\
$\mathrm{~K}$ & $\mathrm{mg} / \mathrm{l}$ & 5 & 400 & 63.41667 & 80.11 \\
$\mathrm{Ca}$ & $\mathrm{mg} / \mathrm{l}$ & 11 & 570 & 139.6667 & 111.03 \\
$\mathrm{Mg}$ & $\mathrm{mg} / \mathrm{l}$ & 15 & 442 & 118.0833 & 109.41 \\
$\mathrm{HCO} 3$ & $\mathrm{mg} / 1$ & 0 & 756 & 293.25 & 153.23 \\
$\mathrm{CO} 3$ & $\mathrm{mg} / 1$ & 0 & 168 & 46 & 34.12 \\
$\mathrm{Cl}$ & $\mathrm{mg} / \mathrm{l}$ & 36 & 5,885 & 899.4167 & 1175.19 \\
$\mathrm{SO} 4$ & $\mathrm{mg} / \mathrm{l}$ & 19 & 1,272 & 354.7222 & 344.26 \\
$\mathrm{PO} 4$ & $\mathrm{mg} / \mathrm{l}$ & 0.1 & 0.1 & 0.1 & 0.1 \\
$\mathrm{NO} 3$ & $\mathrm{mg} / \mathrm{l}$ & 0 & 14 & 5.658333 & 5.30 \\
$\mathrm{~F}$ & $\mathrm{mg} / \mathrm{l}$ & 0.16 & 4.8 & 0.76 & 0.83 \\
$\mathrm{TH}$ & $\mathrm{mg} / \mathrm{l}$ & 138.18 & $2,642.46$ & 835.07 & 662.47 \\
$\mathrm{SAR}$ & - & 0.99 & 20.03 & 5.74 & 4.99 \\
\hline
\end{tabular}

GIS analysis

The base map of Tuticorin coastal area was digitized from survey of India toposheet no 58L/1\&2 and 58L/5 using ArcGIS 9.2 software. The precise locations of sampling points were determined in the field GARMIN 12 Channel GPS and the exact longitudes and latitudes of sampling points and imported in GIS platform. The spatial distribution for groundwater quality parameters such as hardness, $\mathrm{pH}, \mathrm{TDS}, \mathrm{HCO}_{3}, \mathrm{SO}_{4}, \mathrm{NO}_{3}, \mathrm{Ca}, \mathrm{Mg}, \mathrm{Cl}$ and $\mathrm{F}$ were done with the help of spatial analyst modules in ArcGIS 9.2 software.

\section{Result and discussion}

\section{Hydrochemistry}

Understanding the groundwater quality is important as it is the main factor determining its suitability for drinking, agricultural and industrial purposes (Subramani et al. 2005). Table 2 summarizes results of the various physical and chemical parameters including statistical measures such as minimum, maximum, average and standard deviation analyzed groundwater samples from the study area. Results of the descriptive statistics of physical and chemical parameters for the groundwater samples result were compared with the standard guideline values recommended by the World Health Organization. The classifications are desirable, maximum permissible and the values exceed maximum permissible limit are termed as not permissible. The cation concentration indicate that 83,39 and $22 \%$ of the $\mathrm{K}^{+}, \mathrm{Na}^{+}, \mathrm{Ca}^{2+}$ concentrations exceed the WHO limit. Nitrate $\left(\mathrm{NO}_{3}\right)$ concentration of all the water samples within the study area is within the desirable limit (Table 3).

$\mathrm{pH}$ is the measure of the acidity or alkalinity of a solution. A pH of 7 is neutral; lower numbers indicate acidity, and higher numbers indicate alkalinity. During the present investigation, $\mathrm{pH}$ values ranges from 7.1 to 10.2 with an average value 7.7. The $\mathrm{pH}$ value as low as 7.1 was recorded in Meelavitan and the highest was found in Jothi nagar near Sankarapari with a value of 10.2. This shows that the groundwater of the study area is dominantly of alkaline in nature (Fig. 3).

\section{Total dissolved solids}

The distribution of TDS values clearly shows that the entire study area ranges from 530 to $10,200 \mathrm{mg} / \mathrm{l}$, with an average value is $3,016 \mathrm{mg} / \mathrm{l}$. To ascertain the suitability of groundwater of any purposes, it is essential to classify the groundwater depending upon their hydrochemical properties based on their TDS values (Davis and DeWiest 1966; Freeze and Cherrey 1979), which are represented in Tables 4 and 5 respectively. In the study area, $19 \%$ of the groundwater samples are freshwater and rest of the sample represents brackish water type based on the report by Freeze and Cherrey (1979). According to WHO standards, $64 \%$ of the samples has exceeds the permissible limits and only $36 \%$ of the samples are within the permissible limit. Higher value of TDS can be attributed to the contribution of salts from the subsurface lithology and further due to higher residence time of groundwater in contact with the aquifer body. Most of the samples exceed the 1,500 ppm 
Table 3 Groundwater samples of study area exceeding the permissible limits prescribed by WHO 2004 for domestic purposes

\begin{tabular}{|c|c|c|c|c|c|c|}
\hline \multirow{2}{*}{$\begin{array}{l}\text { Water quality } \\
\text { parameters }\end{array}$} & \multirow[t]{2}{*}{ Units } & \multicolumn{2}{|l|}{ WHO (2004) } & \multirow{2}{*}{$\begin{array}{l}\text { Number of samples } \\
\text { exceeding allowable } \\
\text { limits }\end{array}$} & \multirow{2}{*}{$\begin{array}{l}\text { Percentage of } \\
\text { samples } \\
\text { exceeding } \\
\text { allowable } \\
\text { limits }\end{array}$} & \multirow[t]{2}{*}{ Undesirable effects } \\
\hline & & $\begin{array}{l}\text { Most desirable } \\
\text { limits }\end{array}$ & $\begin{array}{l}\text { Maximum allowable } \\
\text { limits }\end{array}$ & & & \\
\hline $\mathrm{pH}$ & - & 6.5 & 8.5 & 02 & 5.56 & Taste \\
\hline $\mathrm{EC}$ & $\mu \mathrm{S} / \mathrm{cm}$ & 780 & 3125 & 16 & 36.48 & \\
\hline TDS & $\mathrm{mg} / \mathrm{l}$ & 500 & 1500 & 23 & 63.94 & $\begin{array}{l}\text { Gastrointestinal } \\
\text { irritation }\end{array}$ \\
\hline $\mathrm{Na}$ & $\mathrm{mg} / \mathrm{l}$ & - & 200 & 14 & 38.92 & \\
\hline K & $\mathrm{mg} / \mathrm{l}$ & - & 10 & 30 & 83.31 & Bitter taste \\
\hline $\mathrm{Ca}$ & $\mathrm{mg} / \mathrm{l}$ & 75 & 200 & 8 & 22.24 & Scale formation \\
\hline $\mathrm{Mg}$ & $\mathrm{mg} / \mathrm{l}$ & 30 & 150 & 11 & 30.58 & \\
\hline $\mathrm{HCO}_{3}$ & $\mathrm{mg} / \mathrm{l}$ & - & 300 & 12 & 33.36 & \\
\hline $\mathrm{Cl}$ & $\mathrm{mg} / \mathrm{l}$ & 200 & 600 & 13 & 36.14 & Salty taste \\
\hline $\mathrm{SO}_{4}$ & $\mathrm{mg} / \mathrm{l}$ & 200 & 400 & 11 & 30.58 & Laxative effective \\
\hline $\mathrm{NO}_{3}$ & $\mathrm{mg} / \mathrm{l}$ & 45 & - & Nil & 0 & Blue baby \\
\hline $\mathrm{F}$ & $\mathrm{mg} / \mathrm{l}$ & - & 1.50 & 03 & 8.4 & Flurosis \\
\hline
\end{tabular}

Fig. 3 Spatial distribution of EC

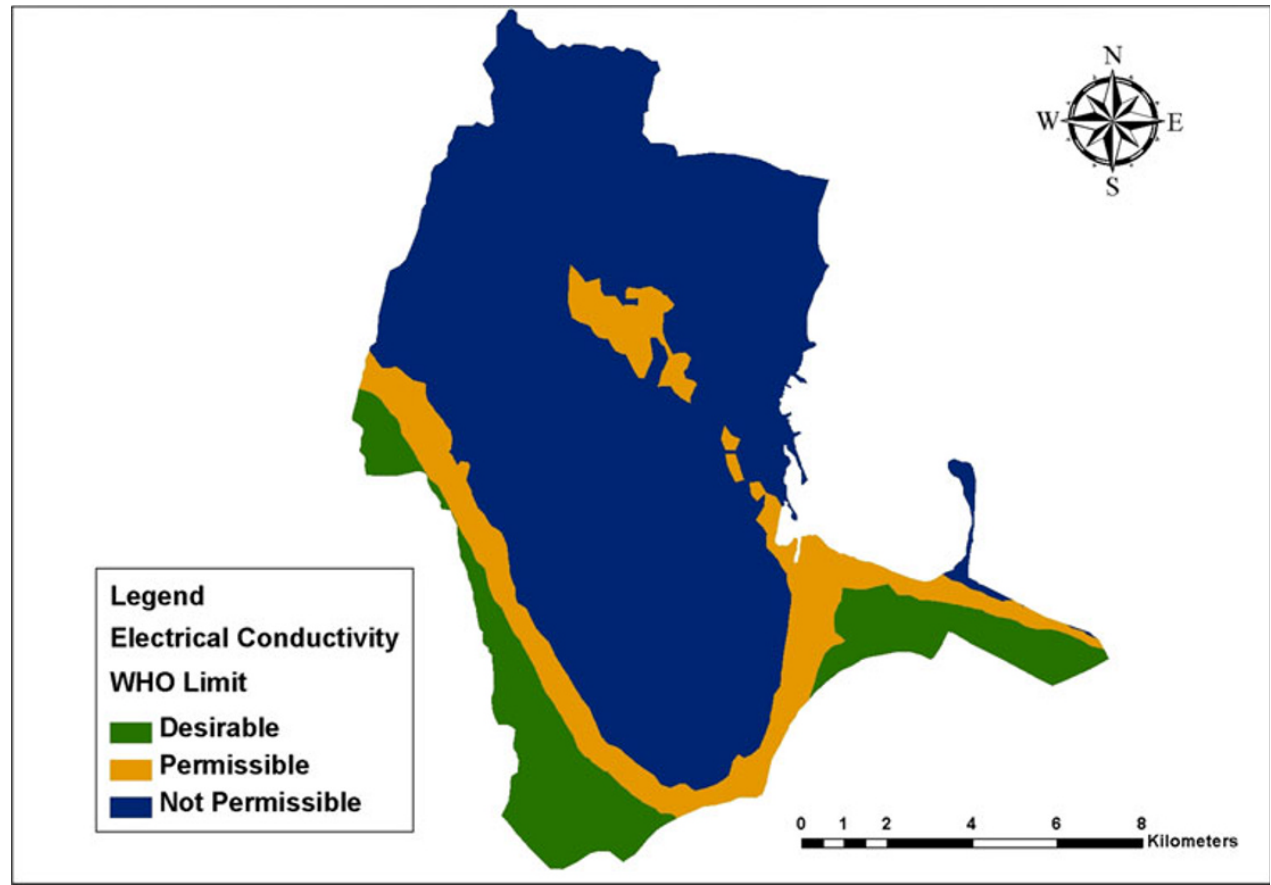

indicates may be attributed to infiltration from the sewage canals unprotected drainages and industrial wastes. The groundwater samples collected from Mappilaiurani, Kalangarai and Thirdmile are within the desirable limit and suitable for drinking purpose without any risk.

\section{Electrical conductivity}

Electrical conductivity (EC) is measure of salt content of water in the form of ions. The EC value is measured in micro-semens per centimeter and is a measure of salt content of water in the form of ions. The EC values ranges from 350 to $19,100 \mu \mathrm{s} / \mathrm{cm}$ with an average value $4,887 \mu \mathrm{s} / \mathrm{cm}$. Electrical conductivity of groundwater within Tuticorin Corporation is given in Table 6 . It is found that $16 \%$ of the samples are within the desirable limit and $39 \%$ of the samples have crossed the permissible limit, but saline waters in $44.3 \%$ of the sample location were dominant in the area according to the WHO standard 2004. Higher EC value may be the indication of seawater intrusion. These 
Table 4 Groundwater classification of all groundwater (TDS- Davis and Dewiest 1966)

\begin{tabular}{lllrl}
\hline $\begin{array}{l}\text { Total Dissolved } \\
\text { Solids }(\mathrm{mg} / \mathrm{l})\end{array}$ & Classification & Sample numbers & $\begin{array}{l}\text { Number of } \\
\text { sample }\end{array}$ & $\begin{array}{l}\text { Percentage of } \\
\text { samples }\end{array}$ \\
\hline$<500$ & Desirable for drinking & 24 & 1 & 2.78 \\
$500-1,000$ & Permissible for drinking & $4,6,7,17,23,36$ & 6 & 16.66 \\
$1,000-3,000$ & Useful for irrigation & $1,2,3,5,9,11,12,14,15,16,19,20,21,28,29,31,33$ & 17 & 47.23 \\
$>3,000$ & Unfit for drinking and irrigation & $8,10,13,18,22,25,26,27,30,32,34,35$ & 12 & 33.33 \\
Total & & 36 & 36 & 100 \\
\hline
\end{tabular}

Table 5 Groundwater classification of all groundwater (TDS-Freeze and Cherrey 1979)

\begin{tabular}{|c|c|c|c|c|}
\hline $\begin{array}{l}\text { Total dissolved } \\
\text { solids }(\mathrm{mg} / \mathrm{l})\end{array}$ & Classification & Sample numbers & $\begin{array}{l}\text { Number of } \\
\text { sample }\end{array}$ & $\begin{array}{l}\text { Percentage of } \\
\text { samples }\end{array}$ \\
\hline$<1,000$ & Fresh water type & $4,6,7,17,23,24,36$ & 7 & 19.42 \\
\hline $1,000-10,000$ & Brackish water type & $\begin{array}{l}1,2,3,5,8,9,10,11,12,13,14,15,16,19 \\
18,20,21,22,25,27,28,29,30,31,32,33,34,35\end{array}$ & 28 & 77.80 \\
\hline $10,000-100,000$ & Saline water type & 26 & 1 & 2.77 \\
\hline$>100,000$ & Brine water type & Nil & Nil & Nil \\
\hline Total & & 36 & 36 & 100 \\
\hline
\end{tabular}

Table 6 Groundwater classification based on electrical conductivity

\begin{tabular}{|c|c|c|c|c|}
\hline $\begin{array}{l}\text { Electrical } \\
\text { conductivity (mg/l) }\end{array}$ & Classification & Sample numbers & $\begin{array}{l}\text { Number of } \\
\text { sample }\end{array}$ & $\begin{array}{l}\text { Percentage of } \\
\text { samples }\end{array}$ \\
\hline$<1,500$ & Permissible & $4,7,17,23,24,36$ & 6 & 16.67 \\
\hline $1,500-3,000$ & Not permissible & $1,2,6,9,11,12,14,15,16,19,21,28,29,33$ & 14 & 38.99 \\
\hline$>3,000$ & Hazardous & $3,5,8,10,13,18,20,22,25,26,27,30,31,32,34,35$ & 16 & 44.44 \\
\hline Total & & 36 & 36 & 100 \\
\hline
\end{tabular}

groundwater samples had been classified in a more systematic manner using dominating cations and anions. The spatial distribution of EC within the study area has been given the Fig. 3.

Total hardness

Total hardness (TH) ranges from 138.18 to $2,642.46 \mathrm{mg} / \mathrm{l}$ with an average value of $835.07 \mathrm{mg} / \mathrm{l}$. According to WHO standards, the maximum allowable limit of $\mathrm{TH}$ for drinking is $600 \mathrm{mg} / \mathrm{l}$ and the most desirable limit is $300 \mathrm{mg} / \mathrm{l}$. The classification of groundwater based on $\mathrm{TH}$ shows that a majority of the groundwater sample of the study area fall in the very hard water category (Fig. 4). The TH in $\mathrm{mg} / \mathrm{l}$ is determined by the following equation (Todd and David 1959).

$\mathrm{TH} \mathrm{mg} / 1=2.497 \mathrm{Ca}^{2+}+4.115 \mathrm{Mg}^{2+}$

Total hardness of the groundwater samples were calculated and classified according to Sawyer and McCarthy
(1967), and the calculated values are given in the Table 8. Among the 36 groundwater sample, $5.5 \%$ of the samples are under moderately hard, $11 \%$ samples are fall under hard and $83 \%$ sample fall under very hard class in the study area (Table 7). This reveals that the study area experiences very hard water and high hardness level is noticed. According the WHO standards, 16 groundwater sample out of 36 collected exceeds the maximum allowable limit $(600 \mathrm{mg} / \mathrm{l})$. High levels of hardness may effected water supply system, excessive soap consumption, calcification of arteries and cause urinary concretions, diseases of kidney of bladder and stomach disorder (CPCB 2008).

\section{Sulphate}

Sulphate $\left(\mathrm{SO}_{4}\right)$ concentration varies from 19 to $1,272 \mathrm{mg} / \mathrm{l}$ with an average value of $354.72 \mathrm{mg} / \mathrm{l}$. The concentration of sulphate is likely to react with human organs if the value exceeds the maximum allowable limit of $400 \mathrm{mg} / \mathrm{l}$ will 
Fig. 4 Spatial distribution of $\mathrm{TH}$

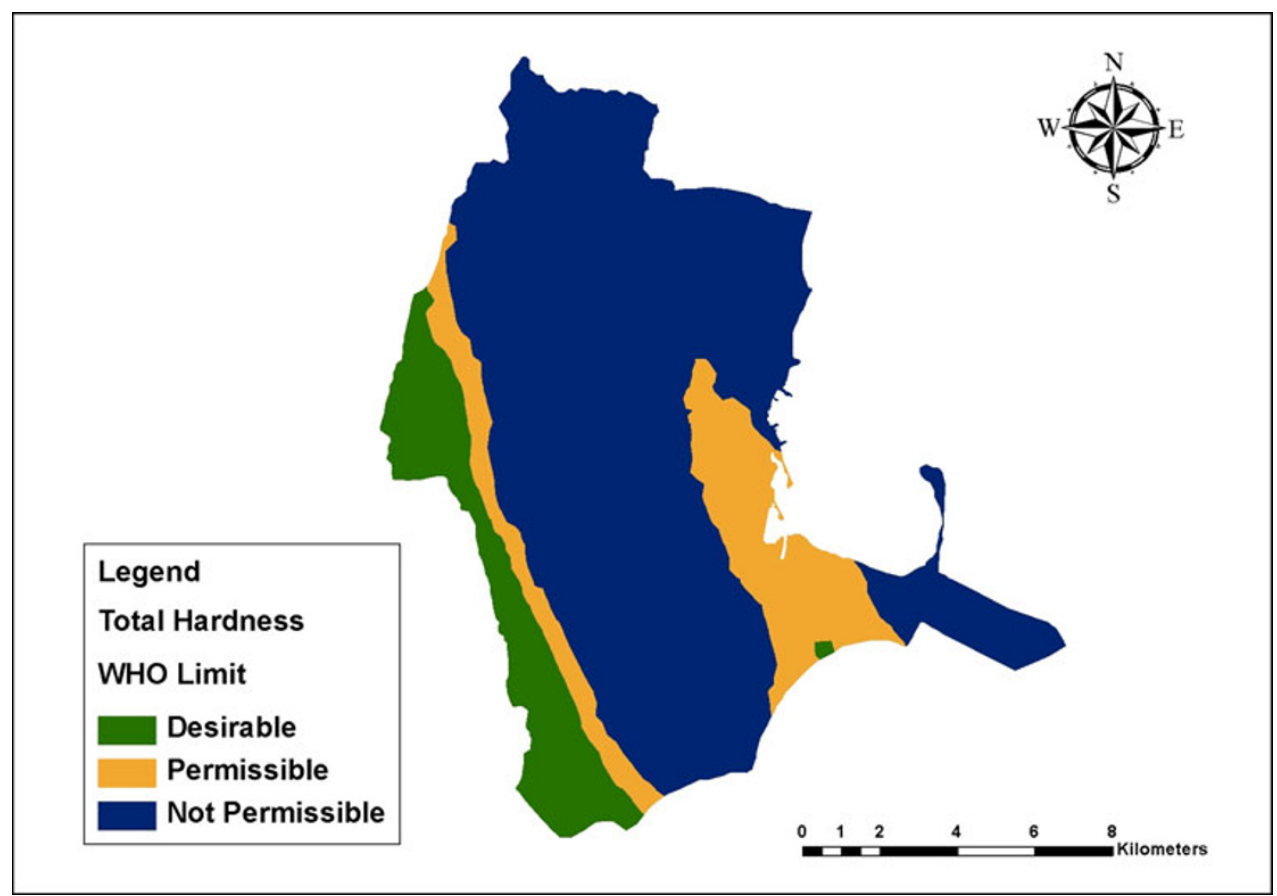

Table 7 Groundwater classification based on hardness (Sawyer and McCarthy 1967)

\begin{tabular}{|c|c|c|c|c|}
\hline $\begin{array}{l}\text { Total Hardness as } \\
\mathrm{CaCO}_{3}(\mathrm{mg} / \mathrm{l})\end{array}$ & Classification & Sample numbers & $\begin{array}{l}\text { Number of } \\
\text { sample }\end{array}$ & $\begin{array}{l}\text { Percentage of } \\
\text { samples }\end{array}$ \\
\hline$<75$ & Soft & - & - & \\
\hline $75-150$ & Moderately high & 20,24 & 2 & 05.55 \\
\hline $150-300$ & Hard & $17,19,21,36$ & 4 & 11.10 \\
\hline$>300$ & Very hard & $\begin{array}{l}1,2,3,4,5,6,7,8,9,10,11,12,13,14,15,16,18 \\
22,23,25,26,27,28,29,30,31,32,33,34,35\end{array}$ & 30 & 83.35 \\
\hline Total & & 36 & 36 & 100 \\
\hline
\end{tabular}

cause a laxative effect on human system with the excess magnesium in groundwater. The sulphate of groundwater of the study area is given Table 2 and it is found that $30.58 \%$ of the samples exceed permissible limits. Most of the samples $(53.6 \%)$ fall in the desirable limit in the study area. The spatial distribution map of sulphate ion concentration in groundwater is presented in Fig. 5.

\section{Chloride}

The chloride $(\mathrm{Cl})$ concentration varies from 36 to $5,885 \mathrm{mg} / \mathrm{l}$ with an average value of $899.41 \mathrm{mg} / \mathrm{l}$. The maximum allowable limit of $\mathrm{Cl}$ is $600 \mathrm{mg} / \mathrm{l}$. The $\mathrm{Cl}$ of groundwater in study area is found that $36.14 \%$ samples exceed permissible limit and $60.4 \%$ sample fall in the maximum allowable limit. Thus, high levels of $\mathrm{Na}$ and $\mathrm{Cl}$ ions in coastal groundwater may indicate a significant effect of seawater mixing (Mondal et al. 2010). High concentration of $\mathrm{Cl}$ may be injurious to some people suffering from diseases of the heart and kidneys, taste, indigestion, corrosion and palatability are effected (CPCB 2008). The spatial distribution map of chlorite ion concentration in groundwater of the study area is shown in Fig. 6.

Nitrate

The nitrate $\left(\mathrm{NO}_{3}\right)$ concentration varies from 0 to $14 \mathrm{mg} / \mathrm{l}$ with an average value of $5.65 \mathrm{mg} / \mathrm{l}$. The $\mathrm{NO}_{3}$ ions concentrations of all the groundwater samples are within the desirable limit of $45 \mathrm{mg} / \mathrm{l}$ as per WHO 2004 standard. The concentration of nitrogen derived from the biosphere (Saleh et al. 1999). Nitrogen is originally fixed from the atmosphere and then mineralized by soil bacteria into ammonium. The high concentration of $\mathrm{NO}_{3}$ in drinking water is toxic and cause blue baby disease/methemoglobinemia in children and also gastric cancer and adversely effects [NS and cardiovascular system (CPCB 2008)]. 
Fig. 5 Spatial distribution of $\mathrm{SO}_{4}$

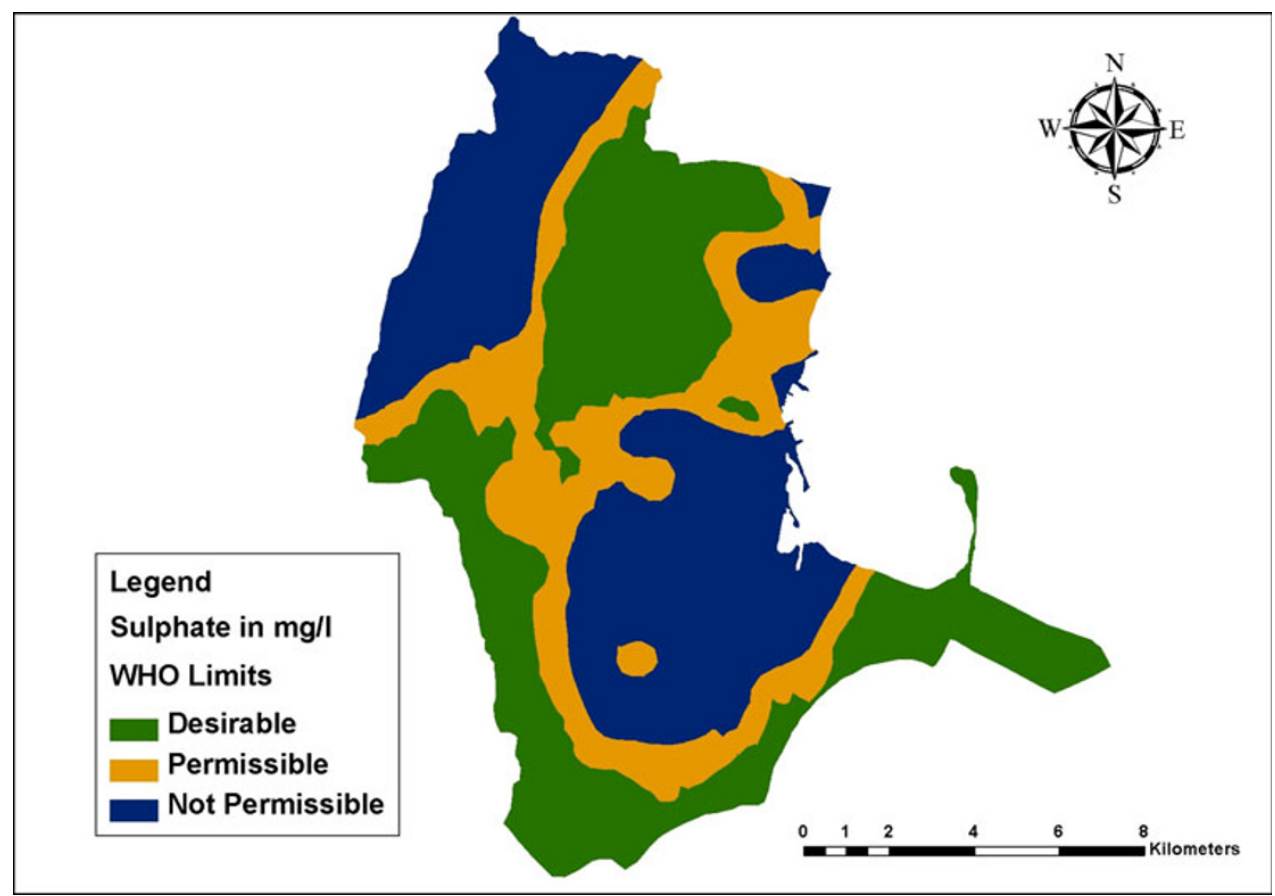

Fig. 6 Spatial distribution of $\mathrm{Cl}$

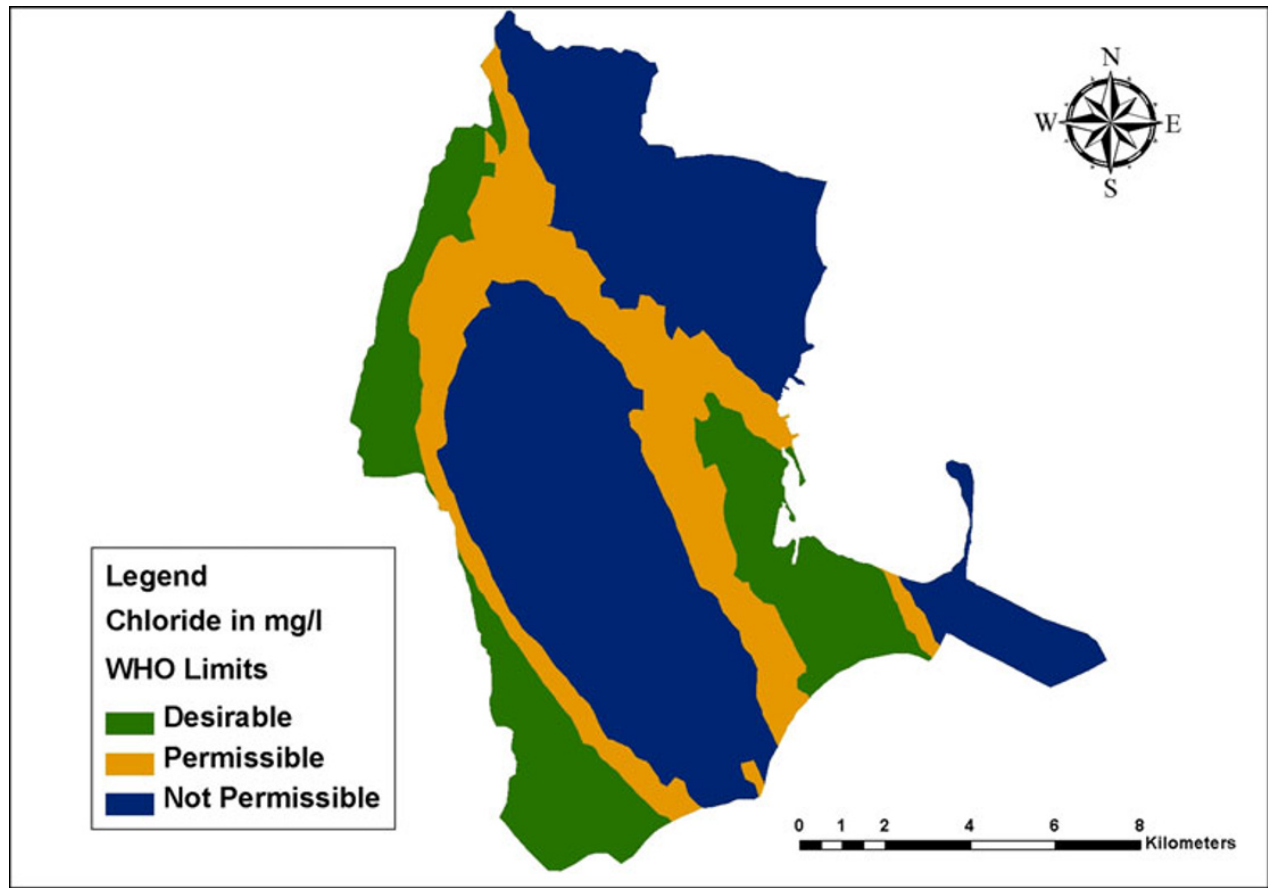

\section{Calcium}

The calcium $(\mathrm{Ca})$ ion concentration varies from 11 to $570 \mathrm{mg} / \mathrm{l}$ with an average value $139.6 \mathrm{mg} / \mathrm{l}$. The maximum allowable limit of calcium ion concentration in groundwater is $200 \mathrm{mg} / \mathrm{l}$ as per WHO 2004 classification. $77.56 \%$ samples fall in the maximum allowable limit of $22.24 \%$ sample exceed the permissible limit. The spatial distribution map of potassium ion concentration in groundwater is of the study area shown in Fig. 7.
Magnesium

The magnesium $(\mathrm{Mg})$ ion concentration varies from 15 to $442 \mathrm{mg} / \mathrm{l}$ with an average value $118 \mathrm{mg} / \mathrm{l}$. The maximum allowable limit is magnesium ion concentration in groundwater is $150 \mathrm{mg} / \mathrm{l}$ as per WHO 2004 classification. $66.48 \%$ samples fall in the maximum allowable limit of $30.58 \%$ samples exceed the permissible limits. The spatial distribution map of potassium ion concentration in groundwater of the study area is shown in Fig. 8. 
Fig. 7 Spatial distribution of $\mathrm{Ca}$

Fig. 8 Spatial distribution of $\mathrm{Mg}$
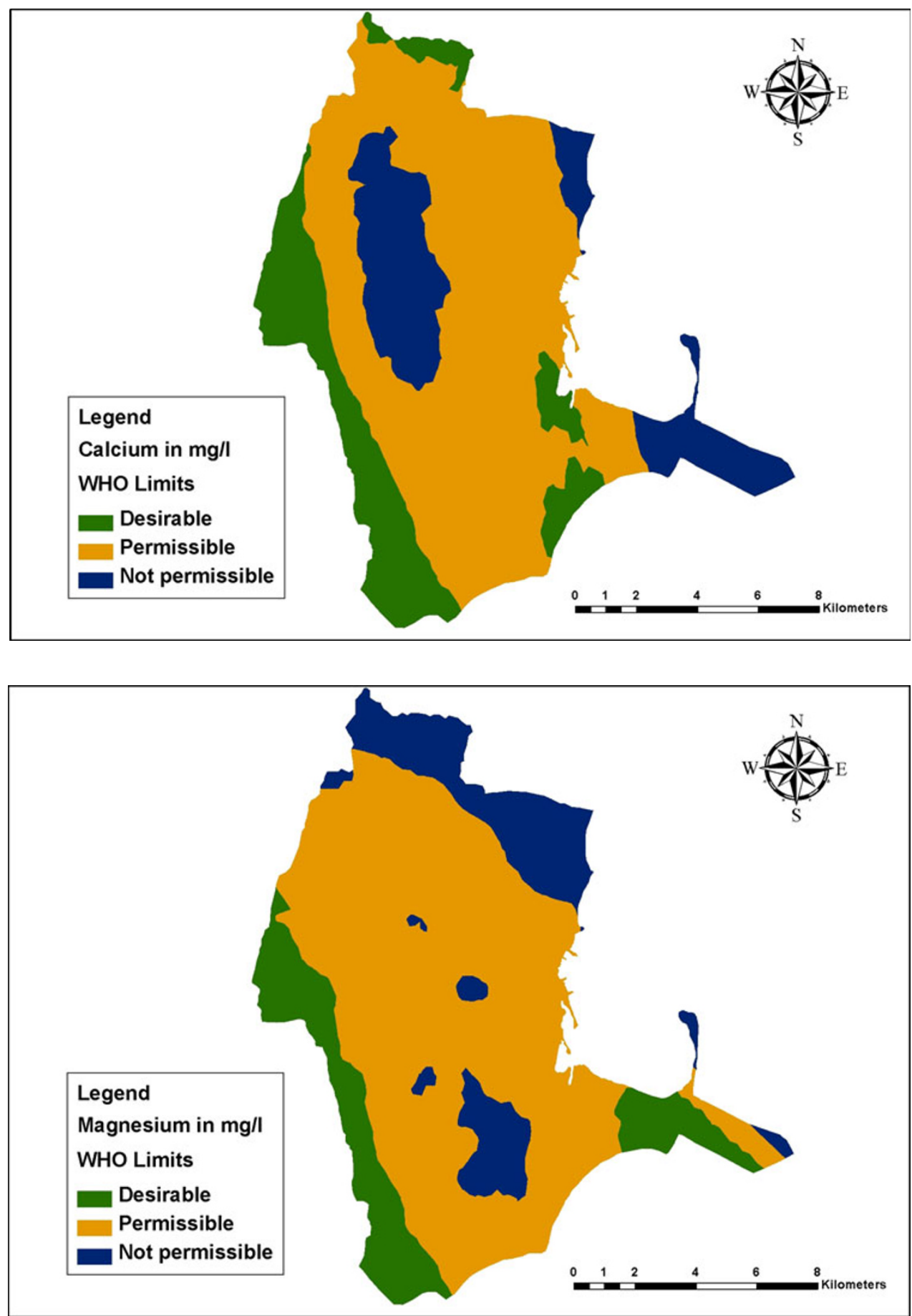

\section{Fluorite}

The fluoride $(\mathrm{F})$ concentration varies from 0.16 to $4.8 \mathrm{mg} / \mathrm{l}$ with an average value of $0.76 \mathrm{mg} / \mathrm{l}$. One of the main trace elements in groundwater is fluoride, which generally occurs as a natural constituent. Bed rock containing fluoride minerals is generally responsible for high concentration of this ion in groundwater (Handa 1975). The fluoride concentration in groundwater of the study area is found that $91.6 \%$ samples are within the maximum allowable limit $(1.5 \mathrm{mg} / \mathrm{l})$ and $8.4 \%$ sample are exceed the permissible limit. The high fluoride content in groundwater leads to dental and skeletal fluorosis such as mottling of teeth and deformation of ligaments (CPCB 2008). The spatial distribution map of chlorite ion concentration in groundwater of the study area is shown in Fig. 9. 
Fig. 9 Spatial distribution of $\mathrm{F}$

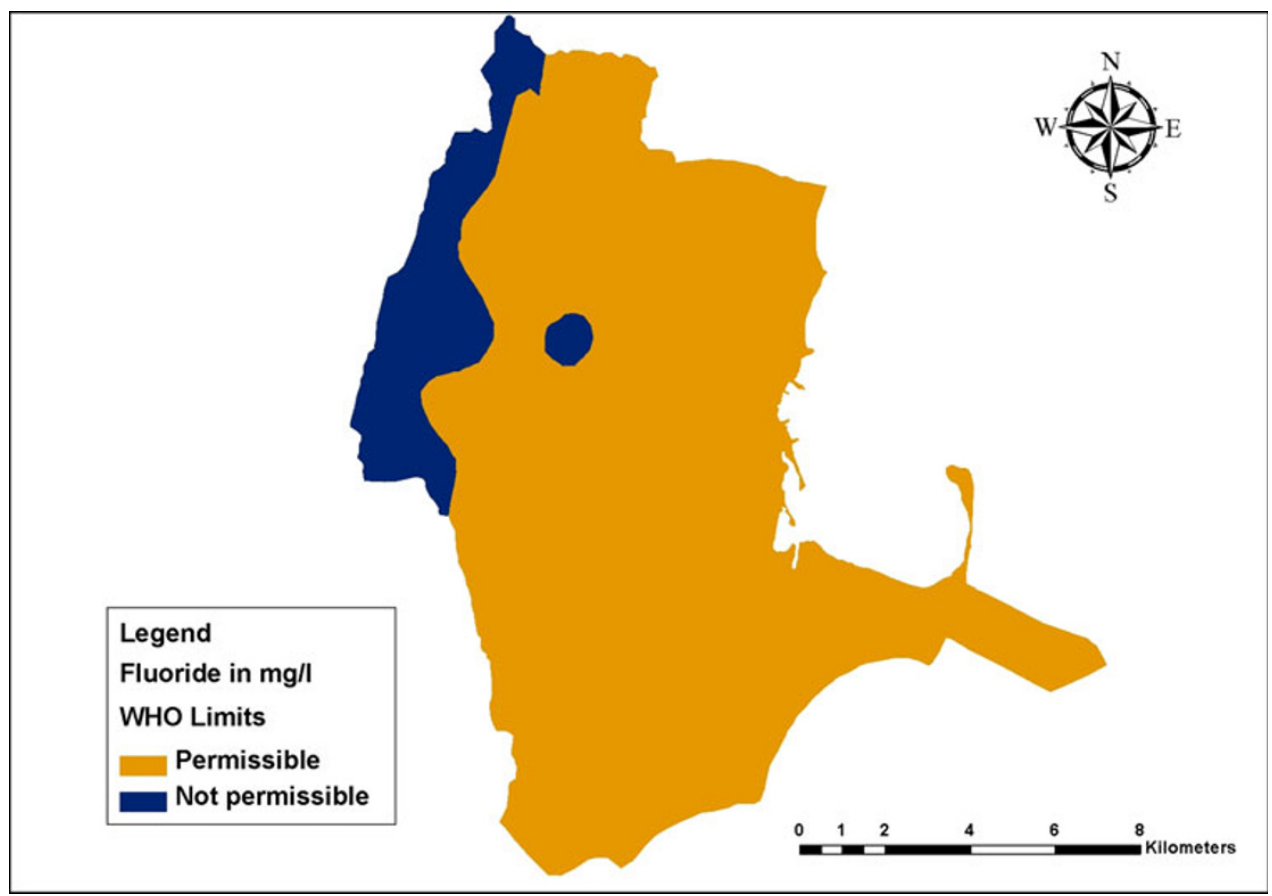

Hydro-chemical facies

The piper diagram is extensively used to be understood by plotting the concentrations of major cations and anions in the Piper trilinear diagram (Piper 1994). On the basis of chemical analysis groundwater is divided into three distinct fields - two triangular fields and one diamond-shaped field. The percentage equivalents per mole values are used for plot. The Aquachem software is used for the plotting of Piper trilinear diagrams (scientific software group Utah, 1998). The overall characteristics of the water is represented in the diamond-shaped fields like namely $\mathrm{Ca}^{2+}-\mathrm{Mg}^{2+}-\mathrm{Cl}^{-}$ $-\mathrm{SO}_{4}{ }^{2-}, \mathrm{Na}^{+}-\mathrm{K}^{+}-\mathrm{Cl}^{-}-\mathrm{SO}_{4}^{2-}, \mathrm{Na}^{+}-\mathrm{K}^{+}-\mathrm{Cl}^{-}-\mathrm{HCO}_{3}{ }^{-}$and $\mathrm{Ca}^{2+}-\mathrm{Mg}^{2+}-\mathrm{HCO}_{3}{ }^{-}$by projecting the position on the plots in the triangular field. In the study area majority of samples belong to $\mathrm{Ca}^{2+}-\mathrm{Mg}^{2+}-\mathrm{Cl}^{-}-\mathrm{SO}_{4}^{2}$ and $\mathrm{Na}^{+}-\mathrm{K}^{+}-\mathrm{Cl}^{-}-\mathrm{SO}_{4}{ }^{2-}$ type (Fig. 10). From the plot, it is observed that an alkali $\left(\mathrm{Na}^{+}\right.$and $\left.\mathrm{K}+\right)$ exceeds the alkaline earths $\left(\mathrm{Ca}^{2+}\right.$ and $\left.\mathrm{Mg}^{2+}\right)$ and strong acids exceeds weak acids. The hydrochemical facies of groundwater is summarized in Table 8.

Classification of groundwater for irrigation water quality

Excessive amount of dissolved ion such as sodium, bicarbonate and carbonate in irrigation water affect plants and soil texture and reducing the productivity of agriculture. The physical effects of these ions are to lower the osmotic pressure in the plant structural cells, thus preventing water from reaching the branches and leaves. The chemical effects disrupt plant metabolism.

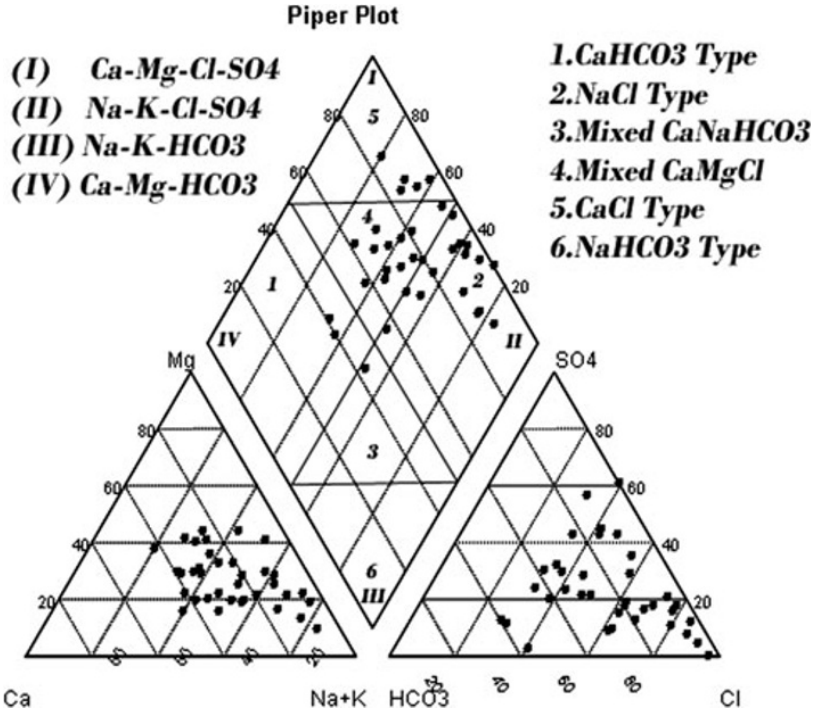

Fig. 10 Piper diagram depicting hydrochemical facies of groundwater

Sodium adsorption ratio

The relative activity of sodium ion in the exchange reaction with soil is expressed in terms of a ratio known as sodium adsorption ratio (SAR). It is an important parameter for determining the suitability of irrigation water, because it is a measure of alkali/sodium hazard for crops. SAR can be estimated by the formula: 
Table 8 Hydrochemical facies of groundwater analytical data

\begin{tabular}{llll}
\hline Facies & Sample numbers & $\begin{array}{l}\text { Number of } \\
\text { samples }\end{array}$ & $\begin{array}{l}\text { Percentage } \\
\text { of samples }\end{array}$ \\
\hline $\mathrm{Ca}^{2+}-\mathrm{Mg}^{2+}-\mathrm{Cl}^{-}-\mathrm{SO}_{4}^{2-}$ & $\begin{array}{c}1,2,4,5,6,9,11,14,15,17,18, \\
23,26,31,32,33,35,36\end{array}$ & 18 & 49.99 \\
$\mathrm{Na}^{+}-\mathrm{K}^{+}-\mathrm{Cl}^{-}-\mathrm{SO}_{4}^{2-}$ & $3,8,10,12,13,19,20,21$, & 41.67 \\
& $22,25,27,28,29,30,34$ & 15 \\
$\mathrm{Na}^{+}-\mathrm{K}^{+}-\mathrm{Cl}^{-}-\mathrm{HCO}_{3}{ }^{-}$ & 16 & 01 & 2.78 \\
$\mathrm{Ca}^{2+}-\mathrm{Mg}^{2+}-\mathrm{HCO}_{3}^{-}$ & 7,24 & 02 & 5.56 \\
Total & 36 & 36 & 100 \\
\hline
\end{tabular}

$\mathrm{SAR}=\frac{\mathrm{Na}^{+}}{\sqrt{\frac{\left(\mathrm{Ca}^{2+}+\mathrm{Mg}^{2+}\right)}{2}}}$

There is a significant relationship between sodium adsorption ratio of irrigation water and the extent to which sodium is absorbed by the soils. If water used for irrigation is high in sodium and low in calcium content, then exchangeable calcium in soil may replace sodium by base exchange reaction in water. This can destroy the soil structure owing to dispersion of the clay particles. The SAR values in the study area range from 0.99 to 20.03 with an average of 5.74 (Table 2). None of the water samples exceeds the SAR value of 12 . So the groundwaters within the study area are suitable for irrigation purpose (Table 9). Based on the Herman Bower classification (1978), all groundwater samples fall under no problem category of irrigation water quality $(S A R<6)$. If the $S A R$ value ranges from 6 to 9 , the irrigation water will cause permeability problems in shrinking and swelling types of clayey soils (Saleh et al. 1999).

The analytical data plotted on the US Salinity Laboratory Diagram (Richards 1954) illustrates that most of the groundwater samples (52.63\% samples) fall in the field of $\mathrm{C} 3 \mathrm{~S} 1$ and $\mathrm{C} 4 \mathrm{~S} 1$ (high to very high salinity with low sodium) waters, indicating very high salinity and low sodium water type, which can be used for irrigation on almost all types of soil with little danger of exchangeable sodium (Fig. 11). Among the water samples collected, $5.56 \%$ of the groundwater fall in the field of $\mathrm{C} 4 \mathrm{~S} 2$ indicating very high salinity and medium sodium hazard. This can be suitable for plants having good salt tolerance, and restricts their suitability for irrigation, especially in soils with restricted drainage (Karanth 1989; Mohan et al. 2000). $2.78 \%$ of the sample fall in the field of $\mathrm{C} 2 \mathrm{~S} 1$ indicating medium salinity and low sodium, C3S2, indicating high salinity and medium sodium, and $\mathrm{C} 4 \mathrm{~S} 3$ falls indicating very high salinity and high sodium hazard in the classification.

Percent sodium

Sodium concentration is important in classifying irrigation water, because sodium reacts with soil to reduce its permeability. Excess sodium in waters produces undesirable effects of changing soil properties and reducing soil permeability (Kelly 1951). Hence, the assessment of sodium concentration is of utmost importance while considering the suitability of irrigation water. In all natural waters percent of sodium content is a parameter to evaluate its suitability for agricultural purposes sodium combining with carbonate can lead to the formation of alkaline soils, whereas sodium combining with chloride form saline soils (Wilcox 1955). Both these soils do not help for the growth of plants. The sodium percentage $(\mathrm{Na} \%)$ is calculated using the formula given below

$\mathrm{Na}^{+} \%=\frac{\mathrm{Na}^{+}+\mathrm{K}^{+}}{\mathrm{Ca}^{2+}+\mathrm{Mg}^{2+}+\mathrm{Na}^{+}+\mathrm{K}^{+}} \times 100$

When the concentration of sodium is high in irrigation water, sodium ions tend to be absorbed by clay particles,

Table 9 Salinity and alkalinity hazard of irrigation water in US salinity diagram

\begin{tabular}{|c|c|c|c|c|}
\hline Classification & SAR/EC & Sample numbers & Number of sample & Percentage of samples \\
\hline $\mathrm{C} 5-\mathrm{S} 4$ & SAR very high EC very high & - & - & - \\
\hline $\mathrm{C} 5-\mathrm{S} 2$ & SAR medium EC very high & - & - & - \\
\hline $\mathrm{C} 4-\mathrm{S} 1$ & SAR low EC high & $1,2,5,9,11,15,16,28,29,33$ & 10 & 28.7 \\
\hline $\mathrm{C} 4-\mathrm{S} 2$ & SAR medium EC high & 13,31 & 2 & 5.56 \\
\hline C4-S3 & SAR low EC low-medium & 20 & 1 & 2.78 \\
\hline $\mathrm{C} 3-\mathrm{S} 1$ & SAR low EC medium-high & $4,6,7,12,14,17,19,23,36$ & 9 & 25.02 \\
\hline $\mathrm{C} 3-\mathrm{S} 2$ & SAR medium EC medium -high & 21 & 1 & 2.78 \\
\hline $\mathrm{C} 2-\mathrm{S} 1$ & SAR low EC moderate & 24 & 1 & 2.78 \\
\hline
\end{tabular}


Fig. 11 US Salinity Laboratory diagram for classification of irrigation waters

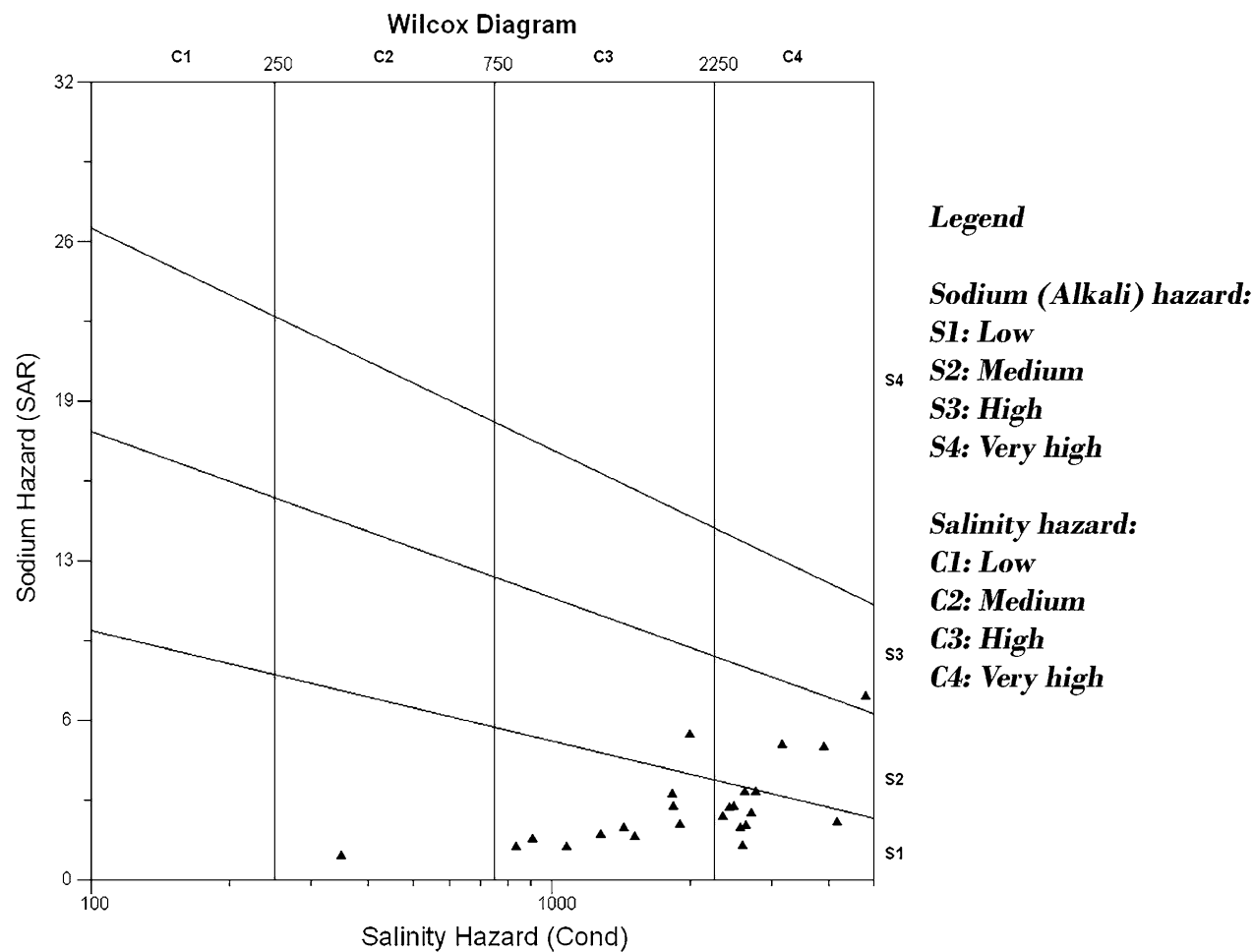

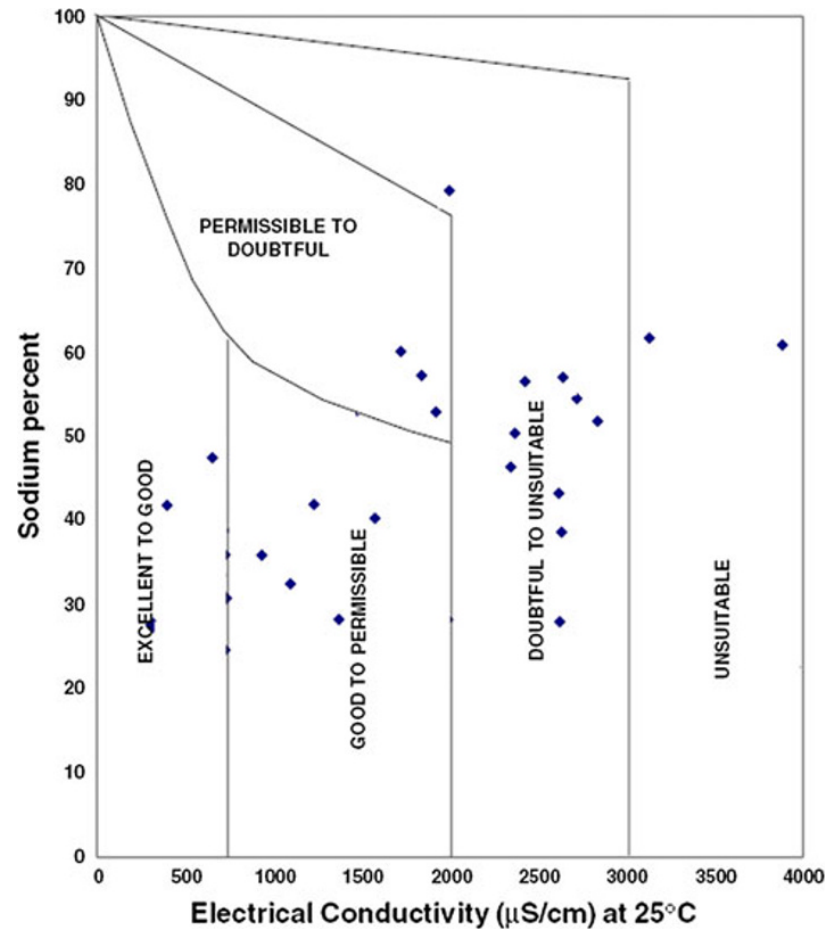

Fig. 12 Percent sodium and electrical conductivity plot (Wilcox 1955)

displacing $\mathrm{Mg}^{2+}$ and $\mathrm{Ca}^{2+}$ ions. This exchange process of $\mathrm{Na}^{+}$in water for $\mathrm{Ca}^{2+}$ and $\mathrm{Mg}^{2+}$ in soil reduces the permeability and eventually results in soil with poor internal drainage. Hence, air and water circulation are restricted during wet conditions, and such soils become usually hard when dry (Saleh et al. 1999).

The classification of groundwater samples with respect to percent sodium (Fig. 12) is shown in Table 10. The groundwater for irrigation purposes by correlating percent sodium (i.e., sodium in irrigation waters) and electrical conductivity. A perusal of Wilcox's 1955 diagram shows that out of 36 samples, $20(55.24 \%)$ belong to the good to permissible; 3 $(8.34 \%)$, excellent to good; $16(44.48 \%)$, doubtful to unsuitable; and $4(11.12 \%)$, unsuitable categories.

\section{Permeability index}

The PI values also indicate suitability of groundwater for irrigation, as the soil permeability is affected by long-term use of irrigation water, influenced by the $\mathrm{Na}^{+}, \mathrm{Ca}^{2+}, \mathrm{Mg}^{2+}$ and $\mathrm{HCO}_{3}{ }^{-}$contents of the soil. The permeability index (PI), as developed by Doneen (1964) indicates the suitability of groundwater for irrigation. It is defined as follows:

$\mathrm{PI}=\frac{\mathrm{Na}^{+}+\sqrt{\mathrm{HCO}_{3}{ }^{-}}}{\mathrm{Ca}^{2+}+\mathrm{Mg}^{2+}+\mathrm{Na}^{+}} \times 100$.

Where the concentrations are reported in milli equivalents per liter

According to permeability indices the groundwaters may be divided into Class I, Class II and Class III types. Class I and Class II water types are suitable for irrigation with $75 \%$ or more of maximum permeability, and Class III types of water with $25 \%$ maximum permeability. The 
Table 10 Irrigation quality of groundwater based on sodium percentage

\begin{tabular}{lllrl}
\hline$\% \mathrm{Na}$ & Classification & Sample numbers & Number of sample & Percentage of samples \\
\hline$<20$ & Excellent & - & - & - \\
$20-40$ & Good & $4,33,36$ & 3 & 8.33 \\
$40-60$ & Permissible & $1,2,5,6,7,9,11,14,15,17,18,23,24,28,29,32,35$ & 17 & 47.24 \\
$60-80$ & Doubtful & $3,8,10,12,16,19,22,25,26,27,30,31$ & 12 & 33.34 \\
$>80$ & Unsuitable & $13,20,21,34$ & 4 & 11.09 \\
Total & & 36 & 36 & 100 \\
\hline
\end{tabular}

permeability index of the Tuticorin area ranges from 15.88 to $103.68 \%$ with an average value of $51.15 \%$. Accordingly, all the 36 samples are categorized under classes 1 and 2 of Doneen's chart (Domenico and Schwartz 1990). World Health Organization uses a criterion for assessing the suitability of water for irrigation based on the permeability index. According to the permeability index values, $95.76 \%$ of the samples fall under class 2 (PI ranged from 25 to $75 \%$ ) and $2.12 \%$ belong to class 1 (PI $>7.5 \%$ ) in the pre-monsoon in 2011.

\section{Conclusion}

The present study has been carried out to evaluate hydrochemical characteristics of groundwaters of the coastal aquifers in Tuticorin, Tamilnadu. GIS has been applied to visualize the spatial distribution of groundwater quality in the study area. A total of 36 groundwater samples were collected and analyzed for various physico-chemical parameters. Very wide ranges and high standard deviations of hydrochemical parameters such as TDS, $\mathrm{EC}, \mathrm{Cl}^{-}, \mathrm{K}, \mathrm{SO}_{4}, \mathrm{Mg}$ suggest the groundwater in the coastal aquifers shows seawater mixing and anthropogenic contamination. Most of the water sample exceeds the maximum permissible limit of WHO standards. The abundance of the major cations and anions are in the following order, $\mathrm{Na}^{+}>\mathrm{Ca}^{2+}>\mathrm{Mg}^{2+}>\mathrm{K}^{+}=\mathrm{Cl}^{-}>$ $\mathrm{HCO}_{3}{ }^{-}>\mathrm{SO}_{4}{ }^{2-}>\mathrm{CO}_{3}>\mathrm{NO}_{3}>\mathrm{PO}_{4}$. Results suggest that the groundwater in this study area is very hard and alkaline in nature. As represented by Piper trilinear diagram, $\mathrm{Ca}^{2+}-\mathrm{Mg}^{2+}-\mathrm{Cl}^{-}-\mathrm{SO}_{4}{ }^{2-}$ facies are the dominant hydrochemical facies in the groundwater of Tuticorin Corporation. From the plot it is observed that an alkali $\left(\mathrm{Na}^{+}\right.$and $\left.\mathrm{K}^{+}\right)$ exceeds the alkaline earths $\left(\mathrm{Ca}^{2+}\right.$ and $\left.\mathrm{Mg}^{2+}\right)$ and strong acids exceeds weak acids. Regarding the TDS, $64 \%$ of the groundwater sample of the study area exceeded the permissible limit. About $84 \%$ of the groundwater sample of the study area exceeded the recommended limit of EC as per the WHO standard. The EC and TDS hydrochemical data clearly shows the consequences of seawater intrusion. The concentration of TH in two-third of the groundwater samples of the study area exceeded the permissible limit as per WHO 2004 standard. This revels that the study area experiences very hard water and high hardness level is noticed. Estimation of sulphate concentration shows $30 \%$ of the groundwater samples exceed the permissible limit. $20 \%$ Chloride ion concentration of the study area is beyond the maximum allowable limit for drinking purpose. The fluoride concentration of the maximum water sample are within the permissible.

Based on the USSL diagram, $52 \%$ of the total sample of the present study area falls under the category of high to very high salinity with low sodium hazards. To overcome this problem we need to plan for better drainage. Based on SAR values $52 \%$ of the groundwater samples are good for irrigation in almost all type of soil with little danger of exchangeable sodium. From the Wilcox Plot, it is observed that most of the samples fall in the permissible-doubtful classes for irrigation purpose. However, permeability index (PI) values indicate that almost all the groundwater sample fall under the class II and suitable for irrigation. It can also be drawn that $\mathrm{Cl}$ concentrations is the major factor that makes up the TDS in the groundwater, and plays an important role in the determination of the quality of groundwater in Tuticorin corporation. Finally, it is concluded that most of the groundwater sample collected within the study area are not suitable for dirking purpose. But it can be used for irrigation and industrial purposes.

Acknowledgments First author is thankful to Department of Science and Technology, Government of India, New Delhi for awarding INSPIRE Fellowship to carry out this study (Ref. No. DST/INSPIRE FELLOWSHIP/2010/(308), Date: 3rd August 2010). Authors are also grateful to Shri A.P.C.V.Chockalingam, Secretary and Dr.C.Veerabahu, Principal, V.O.C College, Tuticorin for his support to carry out study. We are thankful to the anonymous reviewers have provided their valuable suggestions to improve the manuscript.

Open Access This article is distributed under the terms of the Creative Commons Attribution License which permits any use, distribution, and reproduction in any medium, provided the original author(s) and the source are credited.

\section{References}

Adepelumi AA, Ako BD, Ajayi TR, Afolabi O, Omotosa EJ (2009) Delineation of saltwater intrusion into the freshwater aquifer of Lekki Peninsula, Logas, Nigeria. Environ Geol 56:927-933 
Amer AM (1995) Saltwater intrusion in coastal aquifers. In: Proceedings of the international conference on water resources management in arid countries, Muscat, Sultanate of Oman, 12-16 March 1995, 2, pp 521-529

American Public Health Association (APHA), American Water Works Association (AWWA), Water Pollution Control Federation (1995) Standard methods for the examination of water and wastewater, 16th edn. Washington, DC, p 1268

Balasubramanaian AR, Thirugnana S, Chellaswamy R, Radhakrishnan V (1993) Numerical modeling for prediction and control of saltwater enchroment in the coastal aquifers of Tuticorin, Tamil Nadu (21). Tech, Report

Chidambaram S, Senthil Kumar G, Prasanna MV, John Peter A, Ramanathan AL, Srinivasamoorthy K (2009) A study on the hydrogeology and hydrogeochemistry of groundwater from different depths in a coastal aquifer: annamalai Nagar, Tamilnadu, India. Environ Geol 57:59-73

CPCB (2008) Guideline for water quality management. Central Pollution Control Board, Parivesh Bhawan, East Arjun Nagar, Delhi

Dar MA, Sankar K, Dar IA (2010) Fluorine contamination in ground water: a major challenge. Environ Monit Assess 173(1-4):955-968

Dar IA, Sankar K, Dar MA (2011) Spatial assessments of groundwater quality in Mamundiyar Basin, India. Environ Monit Assess 178(1-4):437-447

Davis SN, DeWiest RJ (1966) Hydrogeology. Wiley, Newyork

Domenico PA, Schwartz FW (1990) Physical and Chemical hydrogeology. Wiley, New York, pp 410-420

Doneen LD (1964) Notes on water quality in agriculture. Water Science and Engineering, University of California, Davis

Freeze and Cherrey (1979) Groundwater. Prentice-Hall, New Jersey

Goodchild MF (1993) The state of GIS for environmental problemsolving. In: Goodchild MF, Parks BO, Steyart LT (eds) Environmental modeling with GIS. Oxford University Press, New York, pp 8-15

Handa BK (1975) Geochmistry and genesis of fluoride containing groundwater in India. Groundwater 13(3):275-281

Herman Bower. (1978) Groundwater Hydrology, International Student Edition

Karanth KR (1989) Quality of ground water. In: Karanth KR (ed) Ground water assessment development and management. Tata McGrawHill, New Delhi, pp 217-275

Kelly WP (1951) Alkali soils-their formation, properties and reclamation. Reinhold, New York
Mohan R, Singh AK, Tripathi J, Chowdhary GC (2000) Hydrochemistry and quality assessment of ground water in Naini industrial area, Allahabad District, Uttar Pradesh. J Geol Soc India 55: $77-89$

Mondal NC, Singh VP, Singh VS, Saxena VK (2010) Determining the interaction between groundwater and saline water through groundwater major ions chemistry. J Hydrol 388(1-2):100-111

Piper AM (1994) A graphical procedure in the geochemical interpretation of water analysis. Am Geophys Union Trans 25:914-923

Rajmohan N, Elango L, Elampoornam T (1997) Groundwater quality in Nagai Quaid-Eu Milleth district and Karaikal, South India. Indian Water Resour Soc 17(3):25-30

Rajmohan N, Elango L, Ramachandaran S, Natarajan M (2003) Major ion correlation in groundwater of Kancheepuram Region, South India. Indian J Environ Health 45(1):5-10

Rangarajan R, Mondal NC, Singh VS Singh SV (2009) Estimation of natural recharge and its relation with aquifer parameters in and around Tuticorin town, Tamil Nadu. India Curr Sci 97(2):217-226

Richards LA, Salinity Laboratory US (1954) Diagnosis and improvement of saline and alkaline soils. US Department of Agriculture hand book, Washington, DC p 60

Saleh A, Al-Ruwaih F, Shehata M (1999) Hydrogeochemical processes operating within the main aquifers of Kuwait. J Arid Environ 42:195-209

Sawyer C, McCarthy P (1967) Chemical and sanitary engineering, 2nd edn. McGraw-Hill, New York

Selvam S, Sivasubramanian P (2012) Groundwater potential zone identification using geoelectrical survey: a case study from Medak district, Andhra Pradesh, India. International J Geomatics Geosci 3(1):55-62

Subramani T, Elango L, Damodarasamy SR (2005) Groundwater quality and its suitability for drinking and agricultural use Chithar River Basin, Tamilnadu, India. Environ Geol 47:1099-1110

Todd DK (1959) Groundwater Hydrology. Wiley, New York, p 336

Whittemore DO, Greggor KMM, Marotz GA (1989) Efeects of variations in recharge on groundwater quality. J Hydrol 106:131-145

WHO (2004) Guidelines for drinking water quality, vol 1. Recommendations, 3rd edn. WHO, Geneva, p 515

Wilcox LV (1955) Classification and use of irrigation water. US Department of Agriculture, Washington 969 